DOI: $10.15193 / \mathrm{zntj} / 2018 / 117 / 255$

\author{
IWONA WRZEŚNIEWSKA-WAL
}

\title{
BEZPIECZEŃSTWO UPRAW GMO I ŻYWNOŚCI GM NA PODSTAWIE NOWYCH REGULACJI PRAWNYCH NA POZIOMIE MIECDZYNARODOWYM I KRAJOWYM
}

\begin{abstract}
Streszczenie
Wprowadzenie na rynek nowoczesnych technologii, dzięki którym możliwa jest produkcja żywności GM, nieustannie wymusza powstawanie nowych regulacji prawnych nie tylko na poziomie krajowym, ale i międzynarodowym. Wiąże się to z procesem globalizacji: rozprzestrzeniania się zwyczajów, wartości i technologii w taki sposób, że mają one wpływ na ludzkie życie na świecie. Instrumentem ułatwiającym proces globalizacji są umowy o usuwaniu wzajemnych barier w handlu. Od 2013 roku negocjowane jest nowe porozumienie USA - UE. Jest to umowa o Transatlantyckim Partnerstwie w dziedzinie Handlu i Inwestycji (TTIP), która wiąże się z liberalizacją handlu towarami, a także z usługami w wielu dziedzinach gospodarki Unii Europejskiej i Stanów Zjednoczonych. Rolnictwo jest jednym z najtrudniejszych i najbardziej wrażliwych sektorów w tych negocjacjach. Wynika to z faktu, że Unia Europejska i Stany Zjednoczone mają odmienne podejście do wielu zagadnień dotyczących produkcji i handlu artykułów rolnych i rolno-spożywczych. Przeszkodą w przyszłych negocjacjach jest obszar żywności GM. W Unii Europejskiej Parlament Europejski i Rada UE ustanowiły regulacje prawne wprowadzające surowe procedury postępowania z GMO. Tymczasem w Stanach Zjednoczonych nie ma jednolitej odrębnej regulacji dotyczącej żywności GM. W opracowaniu wskazano na zasadnicze różnice między unijnym modelem prawnym bezpieczeństwa żywności GM uwzględniającym zasadę ostrożności a amerykańskim modelem regulacji posługującym się zasadą równoważności.
\end{abstract}

Słowa kluczowe: żywność GM, globalizacja, bezpieczeństwo żywności, prawo

\section{Wprowadzenie}

Współzależność i integracja państw, gospodarek oraz kultur sprawia, że nowe technologie rozprzestrzeniają się w taki sposób, że mają coraz większy wpływ na ludzkie życie na świecie. W literaturze zjawisko to określa się mianem globalizacji.

Dr n. prawnych, lek med. I. Wrześniewska-Wal, Centrum Medyczne Kształcenia Podyplomowego, Szkoła Zdrowia Publicznego, ul. Kleczewska 61/31, 02-826 Warszawa.

Kontakt: iwona.wrzesniewska-wal@cmkp.edu.pl 
Instrumentem służącym do zarządzania procesem globalizacji są m.in. umowy międzynarodowe. Jedną z nich była negocjowana od 2013 r. przez USA i UE umowa o Transatlantyckim Partnerstwie w dziedzinie Handlu i Inwestycji (TTIP). Pod koniec 2016 r. po 15 rundach rozmów negocjacje zostały przerwane bez zakończenia [4]. W lipcu 2018 r. USA i Unia rozpoczęły nowe rozmowy dotyczące ułatwień we wzajemnym handlu. Porozumienie ma objąć reformę Światowej Organizacji Handlu (WTO) m.in. w kwestii przyspieszenia rozstrzygania sporów. Negocjacje, których ostatecznym celem byłoby całkowite zniesienie barier (celnych i regulacyjnych) w handlu prawie wszystkimi towarami w przyszłości będą również dotyczyć niektórych produktów rolnych (np. soi) [17]. Niemniej jednak odmienne standardy bezpieczeństwa żywności oraz ochrony konsumentów europejskich stanowią istotną przeszkodę w przyszłych negocjacjach. Powodem są rozbieżności pomiędzy UE a USA w kwestiach tak fundamentalnych, jak koncepcja zarządzania ryzykiem oraz poziom ochrony wymaganej przy wprowadzaniu do obrotu żywności GM. W tym zakresie prawo UE uwzględniające zasadę ostrożności jest restrykcyjne, a USA uznają koncepcję istotnej równoważności i nie mają jednolitej regulacji. Tymczasem w Polsce sejm uchwalił zmianę ustawy o mikroorganizmach i organizmach genetycznie zmodyfikowanych, która dostosowuje nasze ustawodawstwo do reguł UE. Nowa ustawa ma umożliwić Polsce wykonanie wyroku Trybunału Sprawiedliwości UE w sprawie C-478/13. Powyższe orzeczenie było wynikiem skargi Komisji Europejskiej, która zarzuciła Polsce, że w krajowym porządku prawnym nie ma regulacji wskazujących na obowiązek powiadamiania właściwych władz polskich o lokalizacji upraw GMO zgodnie z częścią C dyrektywy 2001/18/WE oraz nie ma rejestru lokalizacji tych upraw. Obecnie w Polsce obowiązuje jednak zakaz prowadzenia upraw GMO, co oznacza, że nawet po wprowadzeniu ww. produktów do obrotu stosownymi regulacjami unijnymi nie będzie można ich wprowadzić na terytorium Polski.

\section{Bezpieczeństwo żywności a globalizacja}

Rozwój wymiany handlowej, której sprzyja globalizacja, oprócz wielu niekwestionowanych korzyści stwarza także liczne niebezpieczeństwa. Globalizacja to etapowy proces liberalizacji przepływów towarów, usług, kapitału ludzkiego i finansowego zmierzający do stworzenia zintegrowanej, globalnej przestrzeni budowanej na korporacyjnym ładzie instytucjonalnym, dzięki któremu możliwe staje się funkcjonowanie w skomplikowanej sieci powiązań [19]. Od początku zauważono bowiem, że sprawy związane ze swobodnym przepływem szczególnego rodzaju towaru, jakim jest żywność, mają istotne znaczenie dla zdrowia, a nawet życia konsumentów. Globalizacja generalnie tworzy środowisko niekorzystne dla stanu bezpieczeństwa żywności, co zmusza do przeciwdziałania we wszystkich wymiarach, tj. krajowym, regionalnym oraz globalnym [13]. 
Instrumentem służącym globalizacji miała stać się negocjowana od 2013 r. przez USA i UE umowa o Transatlantyckim Partnerstwie w dziedzinie Handlu i Inwestycji (TTIP). W ramach TTIP do października 2016 r. odbyło się 15 rund negocjacyjnych, potem negocjacje zostały przerwane. $\mathrm{W}$ momencie negocjacji nowego porozumienia o ułatwieniach w handlu pomiędzy USA a UE warto zastanowić się, jakie problemy w obszarze rolnictwa pojawiły się w trakcie negocjacji TTIP. Samą umowę o Transatlantyckim Partnerstwie w dziedzinie Handlu i Inwestycji Komisja Europejska definiowała jako porozumienie, które ma zlikwidować bariery handlowe dotyczące licznych gałęzi gospodarki, tak aby ułatwić zakup i sprzedaż dóbr oraz usług między UE a Stanami Zjednoczonymi [24]. Celem miało być usunięcie zbędnych przeszkód w handlu i inwestycjach poprzez osiągnięcie zgodności uregulowań prawnych. Wiele kontrowersji budził temat produktów rolnych. [14]. Należy podkreślić, że od początku rolnictwo było dziedziną newralgiczną w rokowaniach umowy TTIP, ponieważ postrzeganie organizmów zmodyfikowanych genetycznie (GMO), klonowania zwierząt i zdrowia konsumenta wykazuje różne tendencje w USA i w UE [15]. W Stanach Zjednoczonych obowiązują znacznie bardziej liberalne przepisy w tym zakresie - producenci nie mają nawet obowiązku informowania o GMO. W Europie te przepisy są znacznie bardziej restrykcyjne. Wynika to przede wszystkim ze sprzeciwu na liberalizację przepisów ze strony takich krajów, jak Polska [24].

\section{Zasady równoważności i ostrożności}

Fundamentalne różnice w podejściu do żywności GM w USA i w UE wynikają z innych metod oceny ryzyka w kontekście bezpieczeństwa tej żywności. W regulacjach UE ocena ryzyka uwzględnia zasadę ostrożności, a w USA - zasadę równoważności. Początkowo amerykańscy naukowcy z rezerwą podchodzili do organizmów genetycznie zmodyfikowanych. Zwracano wówczas uwagę na brak wiedzy, co do konsekwencji stosowania nowej technologii [26]. Z czasem zaczęto jednak dostrzegać komercyjny potencjał biotechnologii, co wpłynęło na potraktowanie zasad bezpieczeństwa jako drugorzędnych [16].

Konsumenci w Europie po raz pierwszy dowiedzieli się o genetycznie zmodyfikowanej żywności w 1996 r., kiedy zaczęto sprowadzać soję uprawianą w USA, odporną na herbicydy. W USA soję GMO mieszano z konwencjonalnymi nasionami i eksportowano do Europy. Pomimo że Europejczycy nie mieli zaufania do amerykańskiej soi, to Amerykańskie Stowarzyszenie Producentów Soi odmówiło oddzielania ziarniaków genetycznie zmodyfikowanych, uzasadniając, że jest ona „równoważnym substytutem” soi zwyczajnej. Pomysł „istotnej równoważności” rozwijany przez WHO, WTO i OECD [30] zakładał, że żywność GM jest zasadniczo taka sama jak naturalna. Stanowisko to przyjęła amerykańska Agencja Żywności i Leków (FDA), która już na początku lat 90. XX wieku, kiedy w USA wprowadzano do uprawy pierw- 
sze rośliny transgeniczne, stwierdziła, że tego typu surowce nie różnią się od roślin konwencjonalnych. Jest to tzw. podejście sektorowe, w ramach którego GMO traktowane jest jak każdy inny składnik danego produktu i poddawane regulacjom dotyczącym całego produktu w ramach istniejących systemów prawnych dotyczących żywności i ochrony roślin [19].

Nasilający się eksport amerykańskiej soi i kukurydzy do Europy oraz różnice występujące w prawodawstwie poszczególnych państw członkowskich dotyczące żywności GM miały bezpośredni wpływ na decyzję o wprowadzeniu nowego instrumentu prawnego, który na podstawie zasady „istotnej równoważności” miał zagwarantować bezpieczeństwo wprowadzanej na rynek żywności GM i jej składników. Tym instrumentem było Rozporządzenie WE nr 258/97 z dnia 27 stycznia 1997 r. dotyczące nowej żywności i nowych składników żywności [22] wprowadzające uproszczony tryb wydawania zezwoleń (bez oceny zagrożeń) stosowany do produktów spożywczych, które zawierają GMO, ale mogą być uznane za „zasadniczo równoważne” z żywnością konwencjonalną. Jednak samo rozporządzenie WE nr 258/97 ani też inne regulacje prawne nie wyjaśniają, jakie przesłanki mają być spełnione do uznania tej równoważności [25]. Niedoskonałości związane z brakiem definicji terminu ,zasadniczo równoważne" w rozporządzeniu WE nr 258/97 stanowią tylko fragment problemu bezpieczeństwa żywności [12]. Błąd tej metody tkwi w tym, że bazuje ona na ryzyku, jakie może wypływać ze znanych wskaźników i ignoruje niezamierzone efekty czynników jeszcze niepoznanych. I tak na przykład genetycznie zmodyfikowana żywność może zawierać nieznane nowe cząsteczki, które mogą być toksyczne lub powodować reakcje alergiczne. Zaznaczyć też trzeba, że metoda równoważnej substytucji jest niezgodna z koncepcją badań naukowych, ponieważ nie dopuszcza badania produktów zmodyfikowanych genetycznie przy założeniu, że nie powodują one zmian, które są bardziej niebezpieczne niż w tradycyjnych produktach [28]. Na podstawie tych rozważań można stwierdzić, że stosowanie zasady ,istotnej równoważności”, jako podstawy oceny ryzyka, jest bardzo niedoskonałe i nie można na niej polegać jako na jedynym kryterium przy ocenianiu bezpieczeństwa żywności. Podejście takie sprawia, że w przypadku „istotnej równoważności” ocena ryzyka staje się narzędziem administracyjnym, a nie oceną bezpieczeństwa żywności [25].

Powyższe wnioski skłoniły ekspertów do stwierdzenia, że środki prawne, które zapewnią bezpieczeństwo żywności, powinny uwzględniać analizę ryzyka. Może ona na podstawie dostępnych informacji i danych w sposób niezależny, obiektywny i przejrzysty ocenić zagrożenie. W procedurze tej doradztwo naukowe szacuje ewentualne zagrożenie zdrowia ludzkiego szczególnie ze strony produktów żywnościowych, metod produkcji, warunków higieny itp. w celu ochrony zdrowia człowieka oraz minimalizowania występowania chorób [11]. Termin analiza ryzyka obejmuje następujące procesy: ocenę ryzyka (opinia naukowa oraz analiza informacji), zarządzanie ryzykiem 
(regulacje prawne i kontrola) oraz komunikacje ryzyka. W przypadku żywności GM największe znaczenie ma jednak zasada ostrożności, która w oczekiwaniu na naukowe dowody umożliwiające bardziej wszechstronną ocenę ryzyka pozwala przyjąć tymczasowe środki zarządzania ryzykiem, konieczne do zapewnienia wysokiego poziomu ochrony zdrowia. W UE dominuje zasada ostrożności, a brak pewności naukowej co do ewentualnych zagrożeń związanych z określonym rodzajem żywności jest podstawą do podejmowania środków prewencyjnych, a w USA dopiero naukowe wykazanie zagrożeń stanowi asumpt do podjęcia działań.

\section{Wprowadzanie żywności GM do obrotu w UE i USA}

Przy wprowadzaniu żywności GM do obrotu na terenie UE, a tym samym i w Polsce, obowiązują restrykcyjne przepisy prawne. Tymczasem w USA jest podejście dość liberalne.

Regulacje przyjęte w UE zorientowane są na ochronę zdrowia i środowiska, a równocześnie mają istotny wpływ na zabezpieczenie funkcjonowania rynku wewnętrznego, w tym swobodnego przepływu towarów. Obowiązujące w tej materii regulacje: Dyrektywa 2001/18/WE w sprawie zamierzonego uwalniania do środowiska naturalnego organizmów zmodyfikowanych genetycznie [3] oraz Rozporządzenie WE nr 1829/2003 w sprawie genetycznie zmodyfikowanej żywności i paszy [20], a także rozporządzenie WE nr 1830/2003 [21], na podstawie którego wprowadzono system umożliwiający prześledzenie (traceability) przepływu produktów GM w łańcuchu produkcji i dystrybucji, stanowią podstawę prawnego modelu bezpieczeństwa wprowadzania na rynek żywności GM w UE. Zgodnie z tymi regulacjami żaden podmiot nie może wprowadzać do obrotu żywności GM, jeśli nie ma zezwolenia udzielonego zgodnie z postanowieniami Rozporządzenia WE nr 1829/2003 w sprawie żywności GM. Jednak zezwolenia na wprowadzenie do obrotu żywności GM nie udziela się, jeśli podmiot występujący o takie zezwolenie nie udowodni w wystarczający sposób, że spełnia ona wymagania dotyczące bezpieczeństwa. Wspomniany podmiot składa wniosek do kompetentnego organu w państwie członkowskim, w którym dany produkt GM ma być po raz pierwszy wprowadzony do obrotu. W Polsce jest to Główny Inspektor Sanitarny. Następnie streszczenie zawartości akt złożonych przez wnioskodawcę (firmę) jest bezzwłocznie przekazywane do Europejskiego Urzędu ds. Bezpieczeństwa Żywności (EFSA). EFSA informuje o wniosku Komisję i pozostałe państwa członkowskie, udostępniając im wniosek oraz wszelkie uzupełniające informacje przekazane przez wnioskodawcę. Ponadto EFSA sporządza streszczenie dokumentacji i udostępnia opinii publicznej, co ma zapewnić większą przejrzystość i przewidywalność omawianych regulacji [10]. Naukowe opinie EFSA są jednym z filarów, na podstawie których opracowywane są regulacje w UE. Opinia naukowa EFSA jest również dostępna dla społeczeństwa. Od dnia opublikowania tej opinii jest 30 dni na zgłaszanie do Komisji 
wszelkich uwag i zastrzeżeń. Procedura konsultacji ze społeczeństwem jest blisko związana z szerszą tendencją do wprowadzania elementów demokracji we współczesnych regulacjach prawnych [18]. Jednak pomimo tylu informacji dotyczących możliwości zgłaszania uwag przez opinię publiczną przepisy rozporządzenia WE $\mathrm{nr}$ 1829/2003 nie regulują podstawowej kwestii: w jaki sposób owe opinie wpłyną na podejmowaną przez Komisje decyzję, czy mają być publikowane, brane pod uwagę czy też ujęte w decyzji dotyczącej zezwolenia na wprowadzenie żywności GM [1]. Należy podkreślić, że $\mathrm{w}$ procedurze wydawania zezwolenia istotną rolę mają opinie naukowe EFSA dotyczące aspektów zdrowotnych i środowiskowych wprowadzanej na rynek żywności GM. Opnie te mogą wywołać bezpośrednie skutki prawne dla wnioskodawców związane z wydaniem zezwolenia bądź odmową. Kolejnym krokiem procedury jest przygotowanie i przyjęcie decyzji dotyczącej wniosku. Formułując projekt Komisja jest zobowiązana do kierowania się wskazaniami zawartymi w opinii EFSA, ale projekt decyzji nie musi być z nią zgodny. W tych sytuacjach Komisja przedstawia te rozbieżności. Następnie projekt decyzji jest głosowany, a Komisja bezzwłocznie informuje wnioskodawcę o podjętej decyzji i publikuje jej szczegóły w Dzienniku Urzędowym WE. Decyzja wydawana jest na 10 lat.

W Europie opinia publiczna domagała się możliwości dokonywania wyboru w sprawie kupowania i spożywania żywności GM. W związku z tym problem ten uregulowano na poziomie rozporządzenia, które określa zakres wymagań dotyczących znakowania produktów zawierających GMO, a także produktów składających się z GMO lub wytworzonych z GMO, niezależnie od tego, czy w produkcie finalnym jest możliwe do zidentyfikowania DNA lub białko pochodzące z modyfikacji genetycznej, czy nie. W praktyce oznacza to obowiązek znakowania takich produktów, jak np. cukier bądź wysoko rafinowane oleje produkowane z surowców zmodyfikowanych genetycznie. Jednak omawiane przepisy nie obejmują produktów otrzymanych za pośrednictwem GMO, czyli takich, które są pozyskiwane z pomocą materiału genetycznie zmodyfikowanego, lecz nie zawierają go w produkcie końcowym (np. ser produkowany za pomocą enzymu zmodyfikowanego genetycznie, który nie występuje jednak w produkcie końcowym). To samo dotyczy mięsa, mleka lub jaj pozyskanych ze/lub od zwierząt karmionych paszą genetycznie zmodyfikowaną, lub które poddawano terapii lekami genetycznie zmodyfikowanymi. Te produkty nie muszą być specjalnie oznakowane. Powyższe wymogi nie mają zastosowania do produktów GM, w których ilość GMO jest mniejsza niż $0,9 \%$ pod warunkiem, że zawartość ta jest niezamierzona lub technicznie nieunikniona.

W USA wprowadzanie żywności GM na rynek nie wymaga uzyskania zezwoleń, jak ma to miejsce w UE. Polityka rządu Stanów Zjednoczonych polega na poszukiwaniu rozwiązań regulacyjnych, które chronią zdrowie i środowisko, przy jednoczesnym zmniejszaniu obciążeń regulacyjnych i unikaniu nieuzasadnionego hamowania inno- 
wacji, wykorzystywania nowych technologii lub tworzeniu barier handlowych. W tym celu w 1986 r. wydano pierwszy dokument poświęcony problematyce biotechnologii rolniczej. Był nim Ujednolicony Dokument Ramowy o Regulowaniu Biotechnologii (Coordinated Framework for Regulation of Biotechnology) [5], który nakreślił kompleksową federalną politykę regulacyjną w celu zapewnienia bezpieczeństwa produktów biotechnologicznych. W dokumencie tym dążono do osiągnięcia równowagi między przepisami zapewniającymi ochronę zdrowia i środowiska przy jednoczesnym zachowaniu wystarczającej elastyczności regulacyjnej, tak aby uniknąć zakłóceń przy wprowadzaniu innowacji. Stwierdzono w nim, że żywność genetycznie zmodyfikowana nie różni się od wyrobów wyprodukowanych konwencjonalnie. Tym samym przedmiotem regulacji amerykańskiego prawa jest produkt, a nie proces. Jednak już w 1992 r. wydano pierwszą aktualizację do powyższego dokumentu, która określała podstawę naukową uwzględniającą ryzyko dla nadzoru nad działaniami wprowadzającymi produkty biotechnologiczne do środowiska [6]. W aktualizacji potwierdzono, że nadzór federalny powinien koncentrować się na charakterystyce produktu, środowisku, w którym jest wprowadzany oraz na zamierzonym wykorzystaniu produktu, a nie na procesie, w którym produkt jest tworzony. Następnie 2 lipca 2015 r. Biuro Wykonawcze Prezydenta (EOP) wydało memorandum „Produkty biotechnologiczne" nawiązujące do produktów opracowanych za pomocą inżynierii genetycznej lub ukierunkowanych, lub in vitro manipulacji informacjami genetycznymi organizmów, w tym roślin, zwierząt i drobnoustrojów [7]. W tym dokumencie doprecyzowano zadania i odpowiedzialność głównych agencji federalnych, które sprawują nadzór nad produktami biotechnologii. W Dokumencie Ramowym o Regulowaniu Biotechnologii nadzór ten powierzono trzem instytucjom: Agencji Żywności i Leków (Food and Drug Administration - FDA), która odpowiada za zapewnienie bezpieczeństwa żywności GM, Amerykańskiej Agencji Ochrony Środowiska (United States Environmental Protection Agency - EPA), która gwarantuje, że GMO będzie bezpieczne dla środowiska oraz Departamentowi Rolnictwa Stanów Zjednoczonych (United States Department of Agriculture - USDA), który w ramach Inspekcji Zdrowia Zwierząt i Roślin (Animal and Plant Health Inspection Service - APHIS) odpowiada za normy prawne w zakresie uwalniania do środowiska nowych gatunków roślin GMO [23]. W strategii zapewnia się, że federalny system regulacyjny jest przygotowany do skutecznej oceny ewentualnych zagrożeń przyszłych produktów biotechnologii [8].

Żywność, w tym żywność GM, podlega wymogom określonym w federalnej ustawie o żywności, lekach i kosmetykach z dnia 25 czerwca 1938 r. (Federal Food, Drug, and Cosmetic Act - FFDCA). Z ustawy tej wynika szereg obowiązków podmiotów zaangażowanych w produkcję, przetwarzanie lub dystrybucję żywności mających na celu zapewnienie bezpieczeństwa żywności. Wytyczne dotyczące sposobu interpretacji FFDCA w odniesieniu do żywności GM zawarte zostały w „Oświadczeniu o poli- 
tyce żywności pochodzącej z nowych odmian roślin" (Statement of Policy: Foods Derived From New Plant Varieties) wydanym w 1992 r. przez FDA [14]. W oświadczeniu tym FDA potwierdziła, że w większości przypadków żywność otrzymywaną z GMO będzie traktować, jak tę pochodzącą z roślin wyhodowanych w sposób konwencjonalny i co do zasady taka żywność jest bezpieczna. Jednakże w odniesieniu do produktu GM, który różni się znacznie strukturą, funkcją lub kompozycją od substancji obecnych w żywności, wymagane jest zatwierdzenie nowej substancji [9].

W USA producent musi samodzielnie ustalić na podstawie ogólnych przepisów prawa żywnościowego, czy jego produkty spełniają wymogi bezpieczeństwa żywności. W procesie oceny bezpieczeństwa głównie podmiot zamierzający wprowadzić żywność GM do obrotu weryfikuje, czy nowy czynnik, który pojawia się w żywności, nie jest toksyczny lub nie wywołuje alergii, a poza tym dokonuje analizy różnic pomiędzy zmodyfikowanym i konwencjonalnym produktem w zakresie wartości odżywczej (np. zawartości białka, tłuszczów, witamin, składników mineralnych). Wyniki takiej oceny przedsiębiorca konsultuje z FDA, w której zespół oceny biotechnologicznej (Biotechnology Evaluation Team), składający się z naukowców specjalizujących się m.in. w biotechnologii, toksykologii, chemii, naukach o żywieniu, na podstawie danych otrzymanych od wnioskującego podmiotu dokonuje oceny bezpieczeństwa i zgodności z prawem nowego środka spożywczego [14].

W USA nie ma prawa wymagającego oznakowania żywności GM lub żywności zawierającej składniki GMO. W odniesieniu do żywności zmodyfikowanej genetycznie FDA stwierdziła w dokumentach dotyczących polityki bezpieczeństwa, że jeśli produkt żywnościowy zmodyfikowany genetycznie nie różni się istotnie od tradycyjnego odpowiednika, nie ma potrzeby znakowania produktu, gdyż nie ma niebezpieczeństwa, przed którym należy ostrzec konsumentów [14]. Przy czym FDA dopuszcza możliwość zamieszczania na etykiecie zarówno informacji o tym, że dana żywność została lub nie została wytworzona z GMO. W przypadku produktów wolnych od GMO istnieje system dobrowolnej certyfikacji. Polega on na autorytatywnym stwierdzeniu niezależnej jednostki (tzw. strony trzeciej), że przedsiębiorca posiada wdrożony system jakości, który w praktyce zapewnia nieobecność składników zmodyfikowanych genetycznie w wyrobach wprowadzanych na rynek.

\section{Regulacje krajowe}

Wyrazem poparcia dla restrykcyjnych przepisów UE jest uchwalona przez polski sejm 22 marca 2018 r. Ustawa o zmianie ustawy o mikroorganizmach i organizmach genetycznie zmodyfikowanych oraz niektórych innych ustaw [27]. Ta nowa regulacja ma realizować cele polityki rolnej UE polegające na zwiększaniu bezpieczeństwa zdrowia ludzi i ochrony środowiska po pierwsze poprzez pełne wdrożenie do polskiego porządku prawnego wszystkich postanowień dyrektywy 2001/18/WE regulującej za- 
gadnienia zamierzonego uwolnienia organizmów genetycznie zmodyfikowanych do środowiska, a po drugie poprzez ustanowienie mechanizmów umożliwiających skuteczną kontrolę oraz ograniczanie upraw GMO. Poprzednio obowiązująca regulacja pozostawała w sprzeczności z dyrektywą 2001/18/WE, ponieważ Polska nie wypełniła obowiązku wynikającego z art. 31 ust. 3 lit. b tej dyrektywy (zagadnienie zgłaszania, rejestracji i informowania społeczeństwa o uprawach GMO). W związku z tym 2 października 2014 r. Trybunał Sprawiedliwości UE wydał wyrok, w którym orzekł, że Rzeczpospolita Polska uchybiła zobowiązaniom ciążącym na niej na mocy art. 31 ust. 3 lit. b tej dyrektywy [29]. Do czasu uchwalenia nowej ustawy w Polsce nie udało się uregulować problemu zgłaszania i rejestracji upraw GMO. W Polsce nie prowadzi się jednak upraw GMO, a jest to możliwe dzięki dyrektywie Parlamentu Europejskiego i Rady (UE) 2015/412 [2], która zmieniała pierwotną dyrektywę 2001/18/WE w zakresie umożliwienia państwom członkowskim ograniczania lub zakazu uprawy organizmów zmodyfikowanych genetycznie na swoim terytorium. Ten nowy akt prawny pozwala państwom członkowskim na wprowadzenie zakazu uprawy roślin GMO bez uzasadniania swojego stanowiska jakimikolwiek dowodami naukowymi. Polska skorzystała z tej możliwości i we wrześniu 2015 r. zgłosiła wyłączenie swojego terytorium spod możliwości uprawy zmodyfikowanej kukurydzy, które dopuszczone są obecnie do obrotu w celu uprawy w Unii Europejskiej. Pomimo to art. 49a ust. 2 - 18 znowelizowanej ustawy o mikroorganizmach i organizmach genetycznie zmodyfikowanych przewiduje ewentualne prowadzenie upraw GMO oraz kwestie zgłaszania ich ministrowi środowiska, co spełnia wymagania art. 31 ust. 3 lit. b) dyrektywy 2001/18/WE w zakresie powiadamiania organów państwa o uprawach GMO, a tym samym wykonuje wyrok Trybunału Sprawiedliwości UE w sprawie C-478/13. Wykonanie ww. wyroku w zakresie prowadzenia upraw GMO jest głównym celem nowelizacji ustawy o mikroorganizmach i organizmach genetycznie zmodyfikowanych. Przeciwnicy tych rozwiązań uważają, że rejestr jest niepotrzebny, skoro i tak brak możliwości uprawiania GMO na terytorium Polski.

Nowe przepisy zakładają zachowanie zasad bezpieczeństwa, ponieważ podmiot planujący uprawę GMO musiałby przede wszystkim udowodnić brak negatywnego wpływu uprawy danej rośliny GMO na bezpieczeństwo środowiska. Prowadzenie uprawy GMO będzie wymagało utworzenia specjalnej strefy jej prowadzenia. Będzie ona możliwa do utworzenia po uzyskaniu zezwolenia, które wydaje minister środowiska po zasięgnięciu opinii ministra właściwego do spraw rolnictwa oraz opinii rady gminy, na której terenie planowana jest uprawa GMO. Ustawa przewiduje konieczność przedłożenia pisemnych oświadczeń właścicieli i użytkowników wieczystych nieruchomości, a także pszczelarzy lub związków pszczelarzy, których nieruchomości lub pasieki są położone $\mathrm{w}$ odległości do $30 \mathrm{~km}$ od granicy gruntu rolnego, na którym ma być prowadzona uprawa GMO, że nie wyrażają oni sprzeciwu w związku z zamiarem 
utworzenia takiej strefy. Kontrola zgodności prowadzonych upraw z przepisami nowej ustawy jest przeprowadzana przez Wojewódzkiego Inspektora Ochrony Roślin i Nasiennictwa, właściwego ze względu na miejsce prowadzenia danej uprawy. Przewidziane są również sankcje karne za prowadzenie uprawy bez zezwolenia.

\section{Podsumowanie}

Do tej pory nie udało się w badaniach naukowych stwierdzić negatywnego wpływu genetycznie zmodyfikowanej żywności na organizm ludzki, ale również nie udało się udowodnić, że jest ona nieszkodliwa. Nadal nieznane są skutki, jakie może wywołać długotrwałe spożywanie produktów GM. Istotne w tym przypadku są względy rynkowe i ekonomiczne. Rośliny GMO odznaczają się bowiem często lepszym smakiem i są bardziej dorodne, co może skłaniać konsumenta do ich zakupu. $\mathrm{Z}$ tego powodu producenci, upowszechniając stosowanie GMO w żywności, korzystają z wolności gospodarczej zagwarantowanej w regulacjach prawa międzynarodowego. W przyszłości instrumentem gwarantującym swobodę obrotu towarami stanie się negocjowane od lipca 2018 r. nowe porozumienie o ułatwieniach w handlu między USA i UE. Nie należy jednak oczekiwać, że nowe porozumienie wprowadzi standardy współpracy gospodarczej w obszarze żywności, których nie potrafiła wdrożyć Światowa Organizacja Handlu. W obszarze żywności GM przeszkodą w tych negocjacjach będzie prawny model w zakresie bezpieczeństwa żywności GM, w UE tworzony na zasadzie ostrożności, a w USA - na zasadzie równoważności. Stany Zjednoczone preferują podejście sektorowe (wertykalne) cechujące się tym, że GMO traktowane jest jak każdy inny składnik danego produktu i poddawane jest regulacjom dotyczącym całego produktu w ramach istniejących systemów prawnych obejmujących żywność, ochronę roślin itp. W praktyce oznacza to, że użycie tego samego zmodyfikowanego organizmu może być inaczej interpretowane, a to uniemożliwia kompleksowość kontroli. Z kolei podejście UE polega na regulacjach horyzontalnych (dyrektywa 2001/18/WE), traktujących GMO jako jedną całość niezależnie od sposobu jego wykorzystania. Nie wyklucza to również istnienia regulacji wertykalnych ze względu na specyfikę produktu, jaką jest żywność GM. Wtórne prawo UE określiło ten standard bezpieczeństwa w Rozporządzeniu WE nr 1829/2003 w sprawie genetycznie zmodyfikowanej żywności i paszy oraz w Rozporządzeniu nr 1830/2003 dotyczącym możliwości śledzenia i etykietowania organizmów zmodyfikowanych genetycznie. Ograniczony zakres rozporządzenia powoduje, że w zakresie nieuregulowanym przepisami wertykalnymi znajdą zastosowanie przepisy horyzontalne zapisane w dyrektywie 2001/18/WE. Mieszany charakter tych regulacji jest podstawą prawnego modelu bezpieczeństwa wprowadzania na rynek żywności genetycznie zmodyfikowanej. Ten sam model obowiązuje w Polsce. Uchwalona 22 marca 2018 r. Ustawa o zmianie ustawy o mikroorganizmach i organizmach 
genetycznie zmodyfikowanych w pełni dostosowuje polskie prawo do restrykcyjnych regulacji UE.

\section{Literatura}

[1] Dąbrowska P.: Recent developments of the GMO regime in the EU: Drawbacks and improvements in relation to food safety. In: Genetically Modified Organisms and EU Law. Food security in Europe and in the world. $2^{\text {nd }}$ International Workshop for Young Scholars, 26.09.2003.

[2] Dyrektywa Parlamentu Europejskiego i Rady (UE) 2015/412 z dnia 11 marca 2015 r. w sprawie zmiany dyrektywy 2001/18/WE w zakresie umożliwienia państwom członkowskim ograniczenia lub zakazu uprawy organizmów zmodyfikowanych genetycznie (GMO) na swoim terytorium. Dz. U. L 68, ss. 1-8, z 13.03.2015.

[3] Dyrektywa Parlamentu Europejskiego i Rady 2001/18/WE z dnia 12 marca 2001 r. w sprawie zamierzonego uwalniania do środowiska organizmów zmodyfikowanych genetycznie i uchylająca dyrektywę Rady 90/220/EWG. Dz. U. L 106, ss. 1-39, z 17.04.2001.

[4] EU negotiating texts in TTIP. [on line]. Dostęp w Internecie [06.08.2018]: http:// trade.ec.europa.eu/doclib/press/index.cfm?id=1230

[5] Executive Office of the President. Office of Science and Technology Policy. Coordinated Framework for Regulation of Biotechnology. 51 FR 23302, 26 June 1986. [on line]. Dostęp w Internecie [5.08.2018]: http://www.aphis.usda.gov/brs/fedregister/coordinated_framework.pdf

[6] Executive Office of the President. Office of Science and Technology Policy. Exercise of Federal Oversight within Scope of Statutory Authority: Planned Introductions of Biotechnology Products Into the Environment. 57 FR 6753, 27 February 1992. [on line]. Dostęp w Internecie [5.08.2018]: https://obamawhitehouse.archives.gov/sites/default/files/microsites/ostp/57_fed_reg_6753_1992.pdf

[7] Executive Office of the President. Office of Science and Technology Policy, Office of Management and Budget, United States Trade Representative, and Council on Environmental Quality. Modernizing the Regulatory System for Biotechnology Products, 2 July 2015. [on line]. Dostęp w Internecie [5.08.2018]: https://obamawhitehouse.archives.gov/sites/default/files/microsites/ostp/ modernizing_the_reg_system_for_biotech_products_memo_final.pdf

[8] Food and Drug Administration: Modernizing the Regulatory System for Biotechnology Products. [on line]. Dostęp w Internecie [5.08.2018]: https://www.fda.gov/AnimalVeterinary/Development ApprovalProcess/BiotechnologyProductsatCVMAnimalsandAnimalFood/ucm520998.htm

[9] Food and Drug Administration: Statement of Policy: Foods Derived from New Plant Varieties. [on line]. Dostęp w Internecie [6.08.2018]: http://www.fda.gov/Food/GuidanceRegulation/ GuidanceDocumentsRegulatoryInformation/Biotechnology/ucm096095.htm

[10] Franzone D.: Polityka Wspólnoty Europejskiej dotycząca organizmów modyfikowanych genetycznie. W: GMO - poznajmy swoje poglądy. Mat. konf. Instytutu Na Rzecz Ekorozwoju, Warszawa, 11-12 kwietnia 2003.

[11] James P., Kemper F., Pascal G.: Europejski Urząd ds. Żywności i Zdrowia Publicznego. Przyszłość doradztwa naukowego w Unii Europejskiej. Żywność, Żywienie, Prawo a Zdrowie, 2000, 1 supl., 22-23.

[12] Jędrośka J.: Prawne aspekty kontroli GMO. W: GMO - poznajmy swoje poglądy. Mat. konf. Instytutu Na Rzecz Ekorozwoju, Warszawa, 11-12 kwietnia 2003.

[13] Kowalczyk S.: Globalizacja, agrobiznes i produkcja żywności. W: Bezpieczeństwo żywności w erze globalizacji. Red. S. Kowalczyk. Oficyna Wydawnicza SGH, Warszawa 2009, s. 21.

[14] Korzycka M., Wojciechowski P.: Regulacja prawna żywności genetycznie zmodyfikowanej w USA i UE w kontekście planowanego Transatlantyckiego Porozumienia Handlowo-Inwestycyjnego (TTIP). Studia Iuridica Lublinensia, 2017, XXVI (1), 465-488.

[15] Krzyżanowski J.: Szanse i zagrożenia dla rolnictwa i konsumentów żywności w krajach Unii Europejskiej. Zagadnienia Ekonomiki Rolnej, 2016, 3 (348), 3-23. 
[16] Kempa-Dymiska A.: Procedura wprowadzania do obrotu organizmów genetycznie zmodyfikowanych w UE i USA. Przegląd Prawa Rolnego, 2013, 1 (12), 153-171.

[17] Kozieł H.: Ameryka i Europa zawarły rozejm w handlu. [on line]. Rzeczpospolita z dnia 26 lipca 2018. Dostęp w Internecie [6.08.2018]: https://www.rp.pl/Gospodarka/307269887-Ameryka-iEuropa-zawarly-rozejm-w-handlu.html

[18] Łętowska E.: Bariery naszego myślenia o prawie w perspektywie integracji z Europą. Państwo i Prawo, 1996, 4-5, 44-58.

[19] Rosińska-Bukowska M.: Procesy globalizacji i ich wpływ na gospodarkę żywnościową i rolnictwo przez pryzmat działalności korporacji transnarodowych. Zesz. Nauk. SGGW w Warszawie. Problemy Rolnictwa Światowego, 2014, 14 (29), zeszyt 1, 97-107.

[20] Rozporządzenie (WE) nr 1829/2003 Parlamentu Europejskiego i Rady z dnia 22 września 2003 w sprawie genetycznie zmodyfikowanej żywności i paszy. Dz. U. L 268, ss. 1-23, z 18.10.2003.

[21] Rozporządzenie (WE) nr 1830/2003 Parlamentu Europejskiego i Rady z dnia 22 września 2003 r. dotyczące możliwości śledzenia i etykietowania organizmów zmodyfikowanych genetycznie oraz możliwości śledzenia żywności i produktów paszowych wyprodukowanych z organizmów zmodyfikowanych genetycznie i zmieniających dyrektywę 2001/18/WE. Dz. U. L 268, ss. 24-28, z 18.10.2003.

[22] Rozporządzenie (WE) nr 258/97 Parlamentu Europejskiego i Rady z dnia 27 stycznia 1997 r. dotyczące nowej żywności i nowych składników żywności. Dz. U. L 43, ss. 1-6, z 14.02.1997.

[23] Shapiro S.A.: Biotechnology and the Design of Regulation. Ecology Law Quarterly, 1990, 17 (1), 170.

[24] Sobkowiak-Czarnecka M.: Umowa o wolnym handlu pomiędzy Unią Europejską a Stanami Zjednoczonymi - szanse i zagrożenia. Zesz. Nauk. Uniwersytetu Szczecińskiego. Współczesne Problemy Ekonomiczne. Globalizacja. Liberalizacja. Etyka, 2015, 11, 79-85.

[25] Sheridan B.: EU Biotechnology Law and Practice: Regulating Genetically Modified and Novel Foods Products. Palladian Law Publishing, Bembridge 2001, p. 143.

[26] Szkarat M.: Żywność genetycznie zmodyfikowana w stosunkach międzynarodowych. Wyd. UMCS, Lublin 2011, s. 267.

[27] Ustawa z dnia 22 marca 2018 r. o zmianie ustawy o mikroorganizmach i organizmach genetycznie zmodyfikowanych oraz niektórych innych ustaw. Dz. U. 2018, poz. 810.

[28] Wrześniewska-Wal I.: Żywność genetycznie modyfikowana. Aspekty prawne. Wyd. UW, Warszawa 2008, ss. 97-98.

[29] Wyroku Trybunału Sprawiedliwości Unii Europejskiej z dnia 2 października 2014 r. - Komisja Europejska przeciwko Rzeczpospolitej Polskiej, sprawa C-478/13. Dz. U. C 421, ss. 15-16, z 24.11.2014.

[30] Zimny J.: Zasady przeprowadzania oceny zagrożenia przed uwolnieniem GMO do środowiska oraz zasady monitorowania obecności GMO podczas przeprowadzania eksperymentów polowych. Mat. konf. IHAR, Radzików, 23 październik 2004.

\title{
SAFETY OF GMO CROPS AND GM FOODS IN THE LIGHT OF NEW LEGAL REGULATIONS AT INTERNATIONAL AND NATIONAL LEVEL
}

\author{
S u m m a ry
}

Modern technologies make it possible to produce GM foods; however, introducing them to the market continuously necessitates creating new legal regulations not only at the national but, also, at the international level. This is linked to the process of globalization, i.e. the spread of customs, values, and technologies so that they impact human life in the world. Instruments facilitating the process of globalization are agreements on the elimination of mutual trade barriers. A new US-EU agreement has been negotiated since 2013. It is an Agreement on the Transatlantic Trade and Investment Partnership (TTIP), which in- 
volves the liberalization of trade in goods as well as services in many sectors of the economy of the European Union and the United States. Agriculture is one of the most difficult and most sensitive sectors in those negotiations. The reason thereof is the fact that, in this field, the European Union and the United States have a different approach to many issues concerning the production of and trade in agricultural products and agric-food products. An obstacle to future negotiations is the GM food area. In the European Union, the European Parliament and the EU Council have enacted legal regulations introducing strict procedures for dealing with GMOs. Meanwhile, in the United States there is no separate uniform regulation regarding GM foods. In the paper, there are indicated fundamental differences between the EU legal model of GM food safety involving the precautionary principle and the US regulatory model using the principle of equivalence.

Key words: GM food, globalization, food safety, law 